\title{
APLIKASI SISTEM PENDUKUNG KEPUTUSAN PEMBERIAN IZIN TRAYEK ANGKUTAN KOTA PADA PEMERINTAH KOTA MANADO
}

\author{
Luther A. Latumakulita ${ }^{1)}$ \\ ${ }^{1)}$ Program Studi Matematika FMIPA Universitas Sam Ratulangi \\ Jl. Kampus Unsrat Manado, 95115 \\ e-mail: alexalatu@gmail.com
}

\begin{abstract}
ABSTRAK
Aplikasi Sistem Pendukung Keputusan Pemberian Izin Trayek Angkutan Kota dirancang untuk memudahkan dan mengefisienkan pemberian izin trayek terhadap angkutan kota dalam lingkup Pemerintah Kota Manado. Kriteria-kriteria yang diperlukan dalam mengeluarkan izin trayek anggkutan kota dimodelkan menggunakan model matematik dengan cara memberikan bobot pada setiap kriteria dengan besaran bobot sesuai dengan tingkat signifikansinya kemudian setiap sub kriteria diberikan nilai numerik antara 0 .. 100 dan dihitung nilai sub total kriteria dengan mengacu pada pembobotan yang telah ditetapkan sebelumnya. Langkah selanjutnya adalah menjumlahkan semua nilai sub total setiap kriteria untuk mendapati nilai total yang dipakai sebagai dasar pendukung keputusan. Analisa resiko menyatakan sub kriteria yang tidak terpenuhi atau mendapat penilaian 0 (nol).
\end{abstract}

Kata kunci: Izin trayek, model matematik, sistem pendukung keputusan

\section{APPLICATION OF DECISION SUPPORT SYSTEMS FOR LICENSE OF PUBLIC ROUTE VEHICLE AT GOVERNMENT OF MANADO REGENCY}

\begin{abstract}
Application of decision support systems for license of public route vehicle was designed for ease and make more effisient the task of Government of Manado Regency in order to granting licence of public route vehicle. Necessary criterias were modeled using mathematical models. Each createrias has certain weighted and every sub criteria given a numerical value between 0 and 100 . The next steps are calculate for sub total value on each createria based on weighted values was define before and then sum up all of sub total values to fine total value witch used as based for making decission. Sub criteria with zero value was explained in risk analisys report.
\end{abstract}

Keywords: License of pubilc route, decision support systems, mathematical models

\section{PENDAHULUAN}

Kebutuhan akan angkutan kota sebagai sarana transportasi sangat diperlukan khususnya diwilayah perkotaan termasuk dikota Manado. Hal ini disebabkan masyarakat Kota Manado termasuk padat dan memiliki mobilitas yang sangat tinggi untuk kegiatan mereka sehari-hari. Tingginya pergerakan tersebut tentunya membutuhkan angkutan yang memadai agar dapat memudahkan dan memperlancar pergerakan orang dari tempat asal ke tempat tujuan tanpa adanya hambatan. Untuk maksud tersebut diwilayah kota Manado membutuhkan sarana angkutan kota yang representative.

Angkutan yang representative adalah angkutan yang dapat melayani masyarakat dengan memadai dan dengan jumlah yang mencukupi, aman, dan nyaman. Angkutan kota (oto mikro) sebagai salah satu jenis angkutan umum yang berkapasitas tempat duduk sedang, yaitu tempat duduk rata-rata 11-12 dan berjarak tempuh sedang, menjadi pilihan masyarakat yang berpenghasilan menengah ke bawah dengan tarif yang relative terjangkau. Saat ini jumlah angkutan kota (oto mikro) kelihatannya sudah jauh 
melebihi dari jumlah kebutuhan masyarakat akan angkutan kota itu sendiri sehingga berpeluang menimbulkan ketidak nyamanan, ketidakamanan, waktu tempuh yang semakin besar, kemacetan dan lain sebagainya.

Penentuan Pemberian Izin Trayek Angkutan Kota pada Pemerintah Kota Manado masih secara konvensional/manual, sehingga belum memberikan kontribusi yang lebih baik pada masyarakat, untuk itulah diperlukan suatu sistem baru yang dapat memberikan kemudahan prosedur, tata kerja, efisien dan efektif.

\section{PERUMUSAN MASALAH}

Berdasarkan latar belakang diatas maka perlu dibangun suatu sistem yang dapat memudahkan dan menyederhanakan pekerjaan dalam pengambilan keputusan (Decision making) oleh Pemerintah Kota Manado dengan mempertimbangkan faktorfaktor pendukung secara obyektif untuk menentukan orang / usaha yang berhak mendapat izin trayek angkutan kota.

\section{TINJAUAN PUSTAKA}

Proses pengambilan keputusan pada dasarnya adalah memilih suatu alternatif. Metode Analitycal Hierarchi Proses (AHP) adalah sebuah hirarki fungsional, dimana suatu masalah kompleks dan tidak terstruktur dipecahkan ke dalam kelompokkelompoknya. Kemudian kelompokkelompok tersebut diatur menjadi suatu bentuk hierarki (Permadi, 1992)

Program Linear merupakan teknik yang banyak digunakan dalam penelitian operasional (operation research). Program Linear ini dipandang sebagai teknik pengambilan keputusan karena dengan pengintegrasian secara serentak dan pelaksanaan operasi secara berurutan waktunya, dengan menggunakan fasilitasfasilitas yang tersedia, keputusan diambil dengan memperhitungkan segala kemungkinan sehingga efisiensi optimal dapat tercapai (Syamsi, 1995)

Perancangan Sistem Pendukung Keputusan Perhitungan biaya pembuatan cetakan plastik. SPK yang dibangun adalah Specific Decision Support Systems (SDSS) yang dirancang dengan cara cepat (quick hit) melalui pendekatan iteratif dan pengembangan secara bertahap. Teknik ini dipilih dengan mempertimbangkan bahwa DSS (Decision Support Systems) yang dibuat adalah sebuah DSS baru, dengan waktu pembuatan yang singkat dan melibatkan pengguna secara aktif ( Daihani, D.U, 2001). Juga Sistem Pendukung Keputusan Pemandu Kenaikan Pangkat/Jabatan Dosen dengan studi kasus Fakultas MIPA UGM, dimana bertujuan untuk mendukung dan memudahkan para dosen dan administrator sebagai pemandu kenaikan pangkat/jabatan dengan melihat angka kredit yang telah diperoleh. (Anita Desiani, 2003).

Penelitian mengenai analisis kinerja jasa transportasi angkutan kota di kota pekanbaru pernah dilakukan ( M.Yafiz, 2002 ) dimana dijelaskan Kondisi yang terjadi saat ini bahwa meningkatnya permintaan jasa transportasi angkutan kota, belum ditata secara maksimal sehingga pengaturan manajemen angkutan kota belum mampu menawarkan pelayanan yang mmemuaskan. Hal tersebut disebabkan oleh dua faktor, pertama, pengaturan rute dan jalur trayek angkutan kota belum didasarkan pada analisis kebutuhan pasar. Kedua, sikap dan kesadaran berlalu lintas para pengemudi, para penumpang dan juga para petugas terkait relatif masih rendah. Oleh karena itu perlu dilakukan analisis tentang kinerja manajemen angkutan kota yang terintegrasi. Hasil penelitian diketahui bahwa waktu perjalanan bolak balik dari setiap trayek sangat bervariasi, sementara itu tarif yang diberlakukan relatif sama, sehingga merugikan pengusaha jasa transportasi. Lebih lanjut kinerja jasa transportasi dapat dievaluasi dari aspek frekuensi dan varians. Hasil penelitian menunjukkan varians antar frekuensi kendaraan pada saat jam sibuk dan di luar jam sibuk relatif tinggi untuk setiap trayek. hal tersebut menggambarkan adanya permintaan yang tidak stabil antara jumlah kendaraan dengan ketersediaan calon pengguna jasa angkutan kota. Evaluasi kinerja dari aspek load factor yaitu mengukur kapasitas penumpang setiap kali perjalanan apakah setiap trayek mampu mengangkut penumpang dalam kapasitas maksimal. Hasil penelitian menunjukkan bahwa tingkat rata-rata load factor dari seluruh trayek yang ada di kota Pekanbaru baru mencapai $50 \%$ dari kapasitas yang tersedia. Hal tersebut membuktikan bahwa 
jumlah armada angkutan kota sudah melebihi dari target yang ideal dan tidak diperlukan penambahan armada yang baru.

\section{METODE PENELITIAN}

Metode-metode yang digunakan dalam penelitian ini:

1. Studi Kepustakaan yaitu Penelusuran informasi kepustakaan baik mengenai SPK maupun prosedur perizinan trayek angkutan kota.

2. Wawancara dan Observasi, mencari dan mengumpulkan data-data yang ada relevansinya dengan penelitian ini di Lingkungan Pemerintah Kota Manado dan instansi lainnya yang terkait.

3. Merancang, Implementasi dan pengujian terhadap Sistem Pendukung Keputusan Pemberian Izin Trayek Angkutan Kota.

\section{Perancangan Sistem}

Beberapa tahapan dalam perancangan sistem ini adalah sebagai berikut:

- Merancang model matematika yang diperlukan untuk representasi semua Kriteria yang diperlukan

- Merancang Database

- Merancang Input dan Output (I/O)

\section{Perancangan Model Penilaian}

Model penilaian menggunakan model matematika untuk merepresentasikan kriteriakriteria yang diperlukan dalam mengeluarkan izin trayek angkutan kota yaitu kiteria Kelengkapan Berkas, Kelayakan Teknis, Kriteria Usia Kendaraan dan Kriteria Load Factor (Faktor Pemuatan). Setiap kriteria tersebut diberi bobot sesuai dengan signifikansi pengaruh kriteria terhadap dikeluarkannya izin trayek seperti terlihat pada tabel 1 berikut ini:

Tabel 1. Bobot Penilaian Kriteria

\begin{tabular}{|l|c|}
\hline \multicolumn{1}{|c|}{ Kriteria } & Bobot \\
\hline Kriteria Kelengkapan Berkas & $20 \%$ \\
\hline Kriteria Kelayakan Teknis & $30 \%$ \\
\hline Kriteria Usia Kendaraan & $20 \%$ \\
\hline Kriteria Load Faktor & $30 \%$ \\
\hline
\end{tabular}

\section{Model Penilaian Kelengkapan Berkas}

Model penilaian kelengkapan berkas dengan bobot total $20 \%$ dapat dilihat pada tabel 2 .

Tabel 2. Model Penilaian Kelengkapan Berkas

\begin{tabular}{|c|c|c|}
\hline Kriteria Penilaian & Nilai & Bobot \\
\hline $\begin{array}{l}\text { Fotocopy KTP : } \\
\text { - Ya } \\
\text { - Tidak } \\
\text { Fotocopy STNK : } \\
\text { - Ya } \\
\text { - Tidak } \\
\text { Surat Pernyataan memiliki } \\
\text { fasilitas penyimpanan : } \\
\text { - Ya } \\
\text { - Tidak } \\
\text { Surat Pernyataan memiliki } \\
\text { fasilitas perawatan : } \\
\text { - Ya } \\
\text { - Tidak } \\
\text { Fotocopy Izin Usaha } \\
\text { Angkutan : } \\
\text { - Ya } \\
\text { - Tidak } \\
\text { Fotocopy Izin Trayek } \\
\text { - Ya } \\
\text { - Tidak } \\
\text { Bukti pelunasan } \\
\text { Raharja Jasa } \\
\text { - Ya } \\
\text { - Tidak } \\
\text { Surat Pengantar Asli } \\
\text { Pengusaha Angkutan : } \\
\text { - Ya } \\
\text { - Tidak } \\
\text { Buku Tanda Uji (KEUR) : } \\
\text { - Ya } \\
\text { - Tidak }\end{array}$ & $\begin{array}{c}100 \\
0 \\
\\
100 \\
0 \\
\\
100 \\
0 \\
\\
100 \\
0\end{array}$ & $20 \%$ \\
\hline
\end{tabular}

\section{Model Penilaian Kelayakan Teknis}

Model penilaian kelayakan teknis dengan bobot total 30\% dapat dilihat pada tabel 3 . 
Tabel 3. Model Penilaian Kelayakan Teknis

\begin{tabular}{|c|c|c|c|}
\hline \multicolumn{2}{|c|}{ Kriteria Penilaian } & Nilai & Bobot \\
\hline $\begin{array}{c}\text { Peralatan } \\
\text { minimal }\end{array}$ & Peralatan maximal & \multirow{5}{*}{$\begin{array}{c}100 \\
90 \\
80 \\
70\end{array}$} & \multirow{10}{*}{$30 \%$} \\
\hline 80 & 100 & & \\
\hline 70 & 80 & & \\
\hline 60 & 70 & & \\
\hline 50 & 60 & & \\
\hline $\begin{array}{c}\text { Sistem } \\
\text { Penerangan } \\
\text { minimal }\end{array}$ & $\begin{array}{l}\text { Sistem penerangan } \\
\text { maximal }\end{array}$ & \multirow{5}{*}{$\begin{array}{c}100 \\
90 \\
80 \\
70\end{array}$} & \\
\hline 80 & 100 & & \\
\hline 70 & 80 & & \\
\hline 60 & 70 & & \\
\hline 50 & 60 & & \\
\hline $\begin{array}{l}\text { Sistem } \\
\text { Kemudi } \\
\text { minimal }\end{array}$ & $\begin{array}{l}\text { Sistem Kemudi } \\
\text { maximal }\end{array}$ & \multirow{5}{*}{$\begin{array}{c}100 \\
90 \\
80 \\
70\end{array}$} & \\
\hline 80 & 100 & & \\
\hline 70 & 80 & & \\
\hline 60 & 70 & & \\
\hline 50 & 60 & & \\
\hline $\begin{array}{l}\text { AsSuspensi } \\
\text { minimal }\end{array}$ & $\begin{array}{l}\text { AsSuspensi } \\
\text { maximal }\end{array}$ & \multirow[b]{2}{*}{100} & \\
\hline 80 & 100 & & \\
\hline 70 & 80 & 90 & \\
\hline 60 & 70 & 80 & \\
\hline 50 & 60 & 70 & \\
\hline $\begin{array}{l}\text { Ban Pelek } \\
\text { minimal }\end{array}$ & $\begin{array}{c}\text { Ban Pelek } \\
\text { maximal }\end{array}$ & \multirow{2}{*}{100} & \\
\hline 80 & 100 & & \\
\hline 70 & 80 & $\begin{array}{l}90 \\
80\end{array}$ & \\
\hline 60 & 70 & $\begin{array}{l}80 \\
70\end{array}$ & \\
\hline 50 & 60 & & \\
\hline $\begin{array}{c}\text { RangkaBodi } \\
\text { minimal }\end{array}$ & $\begin{array}{l}\text { RangkaBodi } \\
\text { maximal }\end{array}$ & \multirow{2}{*}{100} & \\
\hline 80 & 100 & & \\
\hline 70 & 80 & $\begin{array}{l}90 \\
80\end{array}$ & \\
\hline 60 & 70 & $\begin{array}{l}80 \\
70\end{array}$ & \\
\hline 50 & 60 & & \\
\hline $\begin{array}{l}\text { Sistem Rem } \\
\text { minimal }\end{array}$ & $\begin{array}{l}\text { Sistem Rem } \\
\text { maximal }\end{array}$ & \multirow{2}{*}{100} & \\
\hline 80 & 100 & & \\
\hline 70 & 80 & \multirow{3}{*}{$\begin{array}{l}90 \\
80 \\
70\end{array}$} & \\
\hline 60 & 70 & & \\
\hline 50 & 60 & & \\
\hline $\begin{array}{c}\text { Mesin } \\
\text { Transmisi } \\
\text { minimal }\end{array}$ & $\begin{array}{l}\text { Mesin Transmisi } \\
\text { maximal }\end{array}$ & \multirow{5}{*}{$\begin{array}{c}100 \\
90 \\
80 \\
70\end{array}$} & \\
\hline 80 & 100 & & \\
\hline 70 & 80 & & \\
\hline 60 & 70 & & \\
\hline 50 & 60 & & \\
\hline $\begin{array}{c}\text { Lain-lain } \\
\text { minimal }\end{array}$ & Lain-lain maximal & \multirow{5}{*}{$\begin{array}{c}100 \\
90 \\
80 \\
70\end{array}$} & \\
\hline 80 & 100 & & \\
\hline 70 & 80 & & \\
\hline 60 & 70 & & \\
\hline 50 & 60 & & \\
\hline
\end{tabular}

\section{Model Penilaian Usia Kendaraan}

Model penilaian usia kendaraan dengan bobot 20\% dapat dilihat pada tabel 4 .

Tabel 4. Model Penilaian Usia Kendaraan

\begin{tabular}{|c|c|c|c|}
\hline \multicolumn{2}{|c|}{ Kriteria Penilaian } & Nilai & Bobot \\
\cline { 1 - 2 } $\begin{array}{c}\text { Usia } \\
\text { minimal }\end{array}$ & $\begin{array}{c}\text { Usia } \\
\text { maksimal }\end{array}$ & \multirow{2}{*}{100} & \\
\cline { 1 - 2 } 0 & 2 & 80 & \\
2 & 4 & 60 & \multirow{2}{*}{$20 \%$} \\
4 & 6 & 40 & \\
6 & 8 & 20 & \\
8 & 10 & 0 & \\
10 & 100 & & \\
\hline
\end{tabular}

\section{Model Penilaian Load Factor (Faktor Pemuatan)}

Load Faktor adalah faktor pemuatan yang dimiliki oleh trayek dimana anggutan kota beroperasi. Model penilaian Load Factor dengan bobot $30 \%$ dapat dilihat pada tabel 5.

Tabel 5. Model Penilaian Usia Kendaraan

\begin{tabular}{|c|c|c|c|}
\hline \multicolumn{2}{|c|}{ Kriteria Penilaian } & Nilai & Bobot \\
\cline { 1 - 2 } $\begin{array}{l}\text { Load Factor } \\
\text { minimal }\end{array}$ & $\begin{array}{l}\text { Load Factor } \\
\text { maksimal }\end{array}$ & \multirow{2}{*}{100} & \\
\cline { 1 - 2 } 80 & 100 & 80 & $30 \%$ \\
60 & 79 & 40 & \\
40 & 69 & 20 & \\
20 & 39 & 0 & \\
0 & 19 & & \\
\hline
\end{tabular}

\section{Perancangan Database}

Database yang digunakan dalam membangun aplikasi ini adalah MS Accses. Teknik perancangan database menggunakan teknik Entity Relationship Diagram (ERD) seperti terlihat pada gambar 1 . 


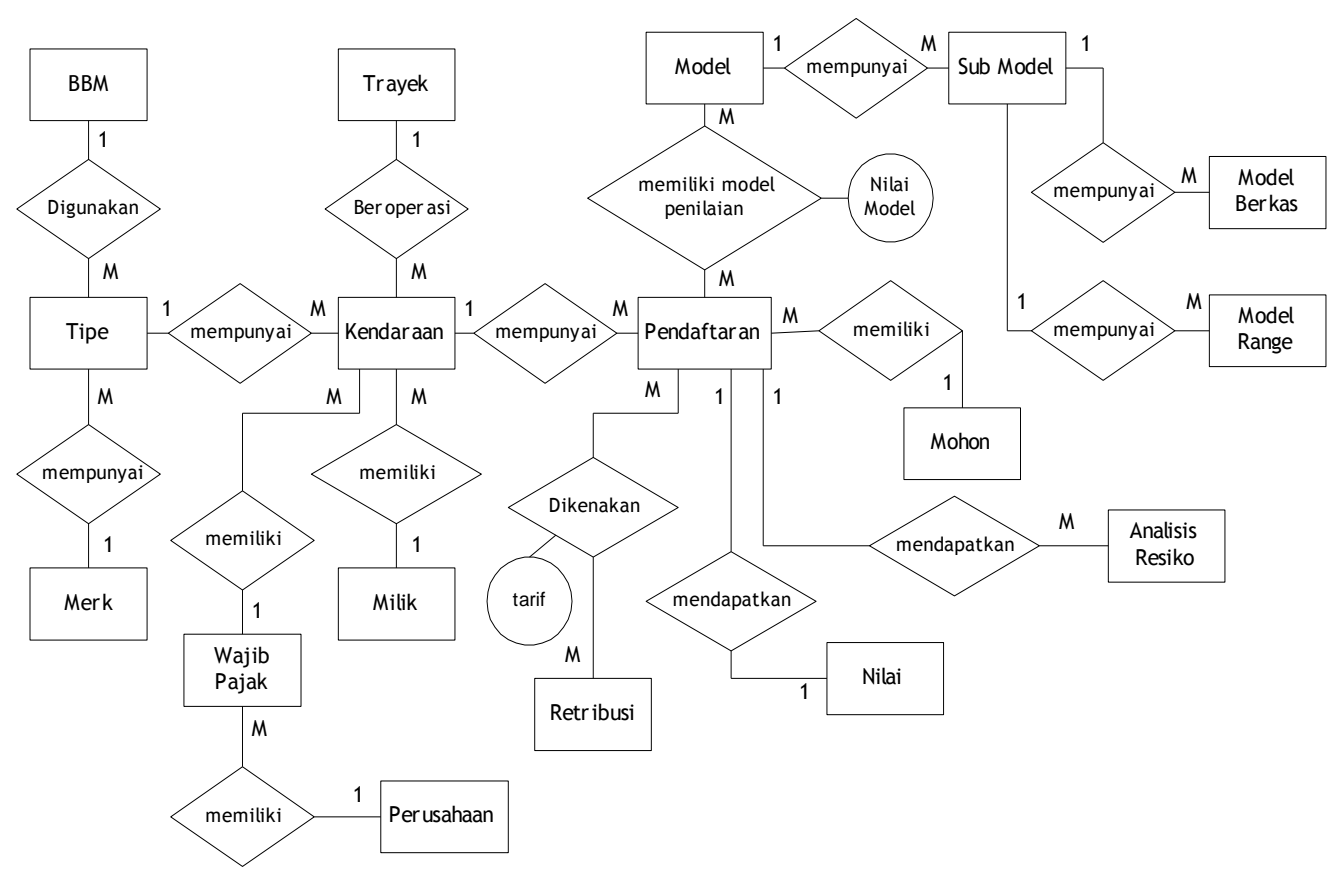

Gambar 1. Diagram Relasi Antar Entitas

\section{HASIL DAN PEMBAHASAN}

Dalam tahapan implementasi, bahasa pemograman yang digunakan adalah Borland Delphi versi 7. Antar muka pengguna dirancang sedemikian sehingga memberikan jaminan keamanan system dari penngunaan secari illegal dengan cara menerapkan proses validasi bertingkat serta memudahkan operator dalam mengoperasikan aplikasi dan seminimal mungkin mencegah terjadinya human error.

\section{Tampilan User Login}

Pada saat program dijalankan user akan diminta memasukan user name dan password kemudian akan di chek keabsahannya serta otoritas user. Otoritas user dibagi dalam tingkatan admin dan operator. User sebagai admin dapat melakukan semua transaksi dan penginputan data master sementara user dengan otoritas operator hanya dikususkan untuk menjalankan operasi pendaftaran, penilaian dan keputusan. Tampilan login user dapat dilihat pada gambar 2 .

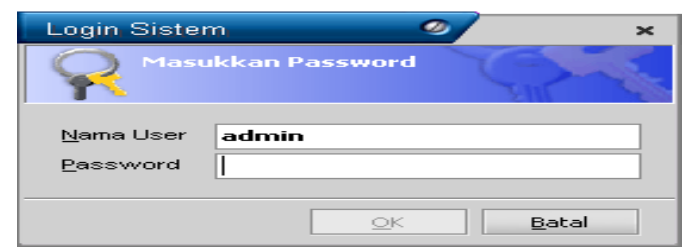

Gambar 2. Tampilan Login User

\section{Tampilan Menu Setup Model}

Menu setup model diperuntukan untuk memberikan bobot pada setip Kriteria. Menu ini hanya dapat dikases opeh user sebagai administrator sistem Tampilan setup model dapat dilihat pada gambar 3 .

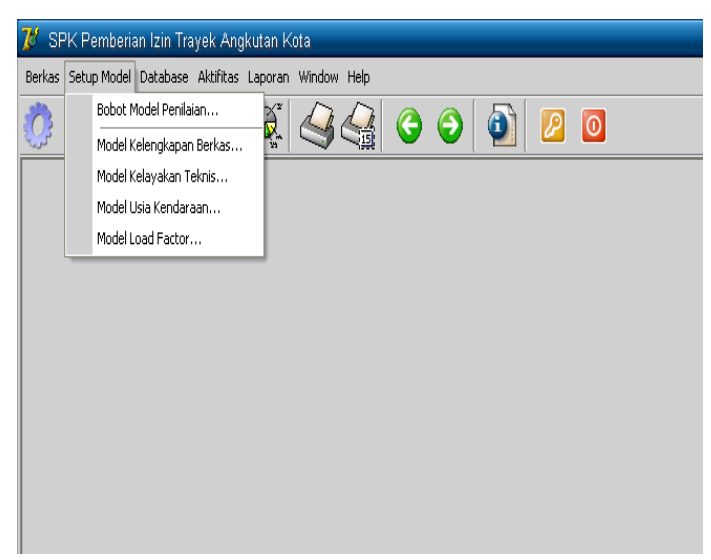

Gambar 3. Tampilan Menu Setup Model 


\section{Tampilan Sub Menu Bobot Model Penilaian}

Sub menu ini dipakai untuk memberikan bobot pada setiap criteria dan dapat dilihat gambar 4.

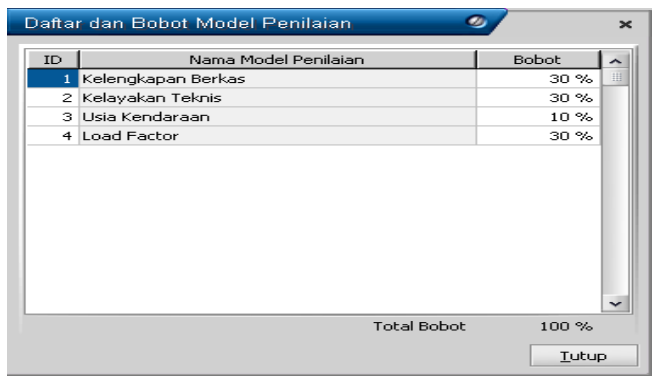

Gambar 4. Tampilan Sub Menu Bobot Model Penilaian

\section{Tampilan Menu Database}

Menu ini diperuntukan untuk menginput semua data master dan hanya dapat diakses oleh operator dengan otoritas sebagai administrator system.

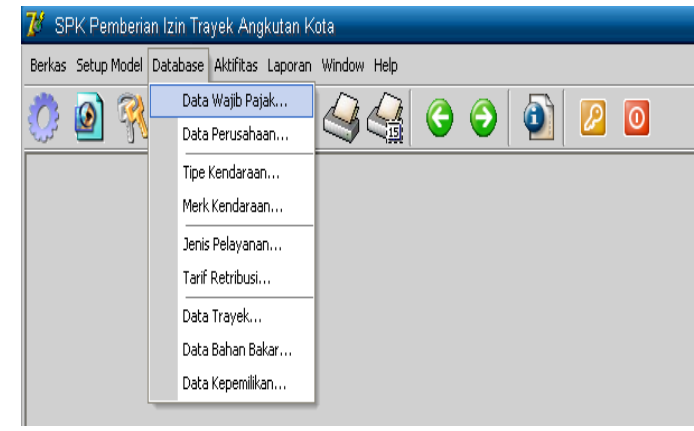

Gambar5. Tampilan Menu Database

\section{Tampilan Sub Menu Pendaftaran}

Pengusulan izin trayek harus terlebih dulu didaftarkan dalam sub menu pendaftaran pada menu aktifitas dan dapat dilihat pada gambar 6.

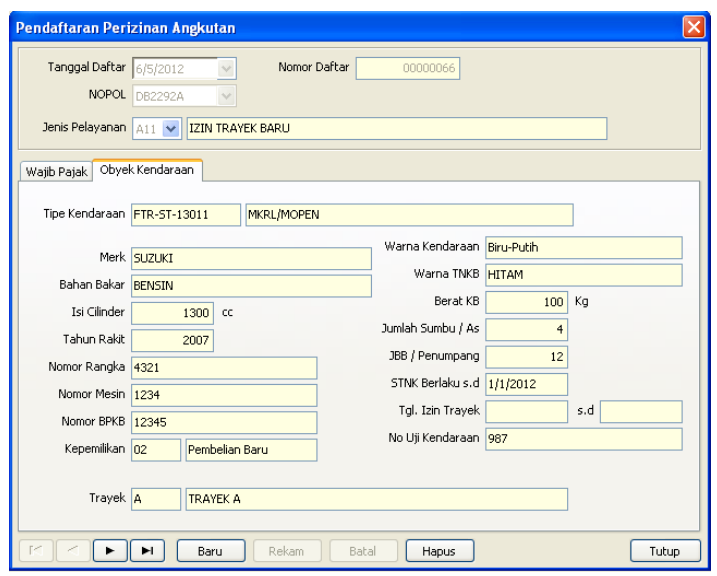

Gambar5. Tampilan Sub Menu Pendaftaran

\section{Tampilan Sub Menu Penilaian}

Dalam sub menu ini dilakukan penilaian terhadap objek kendaraan dan dapat dilihat pada gambar 6 berikut ini:

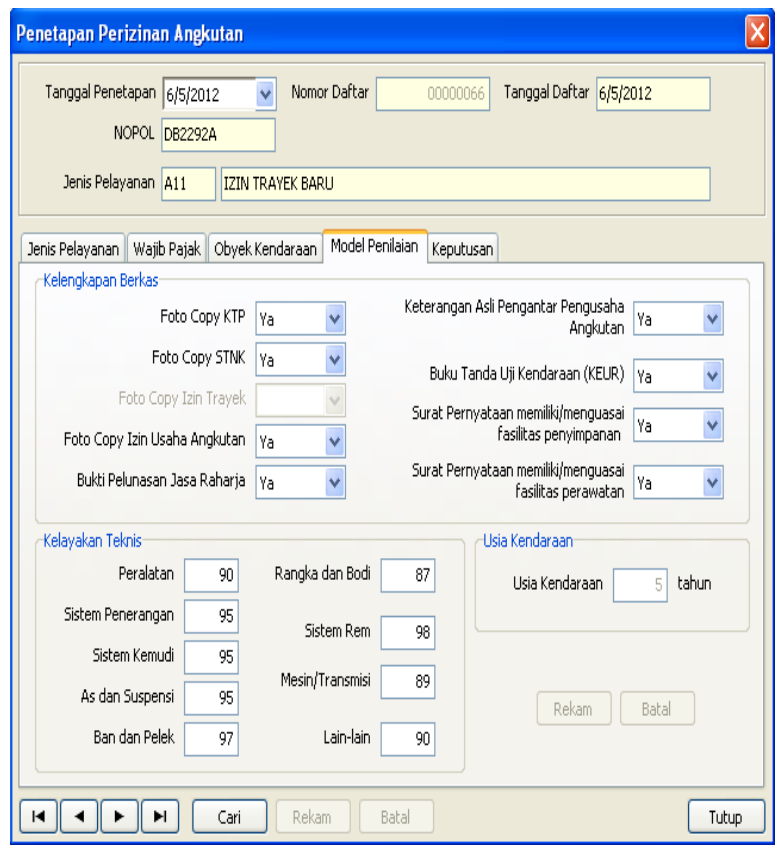

Gambar 6. Tampilan Sub Menu Penilaian

\section{Tampilan Sub Menu Keputusan}

Proses penetapan keputusan dapat dilihat pada tampilan sub menu keputusan seperti pada gambar 7 berikut ini:

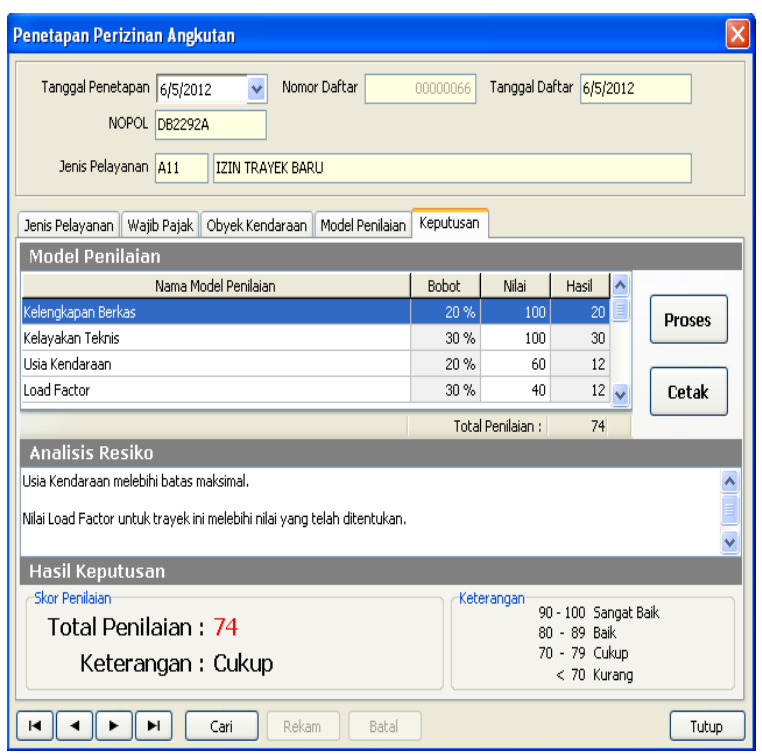

Gambar7. Tampilan Sub Menu Keputusan 


\section{Contoh Laporan Keputusan}

Setelah dilakukan proses keputusan maka hasil keputusan dapat dicetak seperti pada gambar 8 dan gambar 9 .

\begin{tabular}{|c|c|}
\hline \multicolumn{2}{|c|}{$\begin{array}{c}\text { SISTEM PENUNJANG KEPUTUSAN } \\
\text { Pemberian Izin Trayek Angkutan Kota } \\
\text { LAPORAN PENILAIAN }\end{array}$} \\
\hline \multicolumn{2}{|l|}{ DATA WAJIB PAJAK } \\
\hline $\begin{array}{l}\text { Nama Wajib Pajak } \\
\text { Pekerjaan } \\
\text { Alamat } \\
\text { Kode Pos } \\
\text { Nomor KTP } \\
\text { Nama Perusahaan } \\
\text { Alamat Perusahaan } \\
\text { NPWP }\end{array}$ & $\begin{array}{l}\text { Esther Loupatty } \\
\text { WIRASWWASA } \\
\text { Tikala Baru Lingkunganl No. } 35 \text { Manado } \\
95125 \\
01112221 \\
\text { CV. Karunia Indah } \\
\text { Tikala Baru Lingkungan I. } 35 \text { Manado } \\
\text { 12345678 }\end{array}$ \\
\hline \multicolumn{2}{|l|}{ OBYEK KENDARAAN } \\
\hline 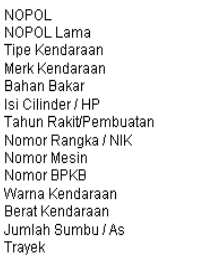 & $\begin{array}{l}\text { DE2292A } \\
\text { MRRLMOPEN } \\
\text { SUZUKI } \\
\text { BENSIN } \\
1300 \mathrm{cC} \\
2007 \\
4321 \\
1234 \\
12345 \\
\text { Biru-Putih } \\
100 \\
4 \\
\text { TRAYEKA }\end{array}$ \\
\hline \multicolumn{2}{|l|}{ MODEL PENILAIAN } \\
\hline $\begin{array}{l}\text { Foto Copy KTP } \\
\text { Foto Copy STNK } \\
\text { Foto Copy lzin Trayek } \\
\text { Foto Copy lzin Usaha Angkutan }\end{array}$ & $\begin{array}{l}\text { Ya } \\
\text { Ya } \\
\text { Ya }\end{array}$ \\
\hline
\end{tabular}

Gambar 8. Laporan Hasil Penilaian (Halaman1)

SISTEM PENUNJANG KEPUTUSAN Pemberian Izin Trayek Angkutan Kota

LAPORAN PENILAIAN

\begin{tabular}{|c|c|c|c|}
\hline PENILAIAN & Nilai & Bobot & Hasil \\
\hline 1. Kelengkapan Berkas & 100 & $20 \%$ & 20 \\
\hline 2. Kelayakan Teknis & 100 & $30 \%$ & 30 \\
\hline 3. Usia Kendaraan & 60 & $20 \%$ & 12 \\
\hline 4. Load Factor & 40 & $30 \%$ & 12 \\
\hline \multicolumn{4}{|l|}{ HASIL PENILAIAN } \\
\hline $\begin{array}{ll}\text { Total Penilaian } & : 74 \\
\text { Keterangan } & : \text { Cukup }\end{array}$ & Penilaian: & $\begin{array}{r}: 90-100 \\
80 \cdot 89 \\
70 \cdot 79 \\
\quad 70\end{array}$ & $\begin{array}{l}\text { Sangat Baik } \\
\text { Baik } \\
\text { Cukup } \\
\text { Kurang }\end{array}$ \\
\hline
\end{tabular}

ANALISIS RESIKO

- Usia Kendaraan melebihi batas maksimal

- Nilai Load Factor untuk trayek ini melebihi nilai yang telah ditentukan.

Gambar 9 Laporan Hasil Penilaian (Halaman2)

\section{KESIMPULAN}

Aplikasi system pendukung keputusan pemberian izin trayek angkutan kota pada pemerintah kota manado dapat meningkatkan efisiensi dan efektifitas dalam proses penerbitan izin trayek karena dengan diimplemantasikan system ini maka proses peneribitan izin trayek tersebut dilakukan berdasarkan data ontentik serta kondisi lapangan sesungguhnya. Selain itu system ini juga dapat dijadikan sebagai basis pengetahuan dalam tingkatan managerial pemerintah kota manado untuk melakukan perencanaan terutama dalam bisang transportasi angkutan kota.

\section{DAFTAR PUSTAKA}

Daihani, D.U. 2001. Komputerisasi Pengambilan Keputusan. Elex Media Komputindo, Kelompok Gramedia, Jakarta.

Desiani, Anita. 2003. Sistem Pendukung Keputusan Pemandu Kenaikan Pangkat/Jabatan Dosen dengan studi kasus Fakultas MIPA UGM [Tesis]. Program Pasca Sarjana Ilmu Komputer Universitas Gajah Mada, Yogyakarta.

Permadi, B. 1992. Analytical Hierarchy Proses. Pusat Antar Universitas-Studi Ekonomi, Universitas Indonesia, Jakarta.

Syamsi, I. 1995. Pengambilan Keputusan dan Sistem Informasi. Bumi Aksara, Jakarta.

Turban, E., dan J.E. Aronson. 1998. Decision Support Systems and Intelligent Systems. Fifth Edition. Prentice-Hall International, Inc New Jersey.

Yafiz,M,12 Oktober2011. http://www.rudyct. tripod.com/sem1_023/grp_indiv5.htm Analisis Kinerja Jasa Transportasi Angkutan Kota di Kota Pekanbaru. 